\title{
The Role of Gastric Urease in Acid Secretion
}

\author{
By R. E. DAVIES AND H. L. KORNBERG \\ Medical Research Council Unit for Research in Cell Metabolism, Department of Biochemistry, \\ The University, Sheffield 10
}

(Received 27 April 1951)

The experiments described in this paper were undertaken to throw light on the possible role of gastric urease in the secretion of hydrochloric acid by the stomach. Mathews (1925) first suggested that gastric hydrochloric acid might be produced by the reaction $\mathrm{NH}_{4} \mathrm{Cl} \rightarrow \mathrm{NH}_{3}+\mathrm{HCl}$, and Luck (1924) showed that ammonia can be formed from urea by suspensions of ground dog gastric mucosa. Rigoni (1930), Martin (1932), Cardin (1933), Mann \& Mann (1939), and Martinson (1950), all suggested that ammonium ions, derived from the enzymic hydrolysis of urea, form hydrogen ions according to the hypothesis of Mathews (1925).

Histochemical investigations by LinderstrømLang \& Ohlsen (1936) on dog mucosa, and Glick $(1949 a)$, on human stomachs, showed that the urease is localized in the oxyntic-cell region of the stomach. Glick (1949a) wrote 'the intensity of the (urease) activity appeared to be proportional to the acid-secretory response elicited by histamine', and put forward a tentative scheme for the formation of hydrochloric acid from the enzymic decomposition of urea. Luck \& Seth (1925) first suggested that a possible function of the urease is to protect the mucosa from attack by acid.

All these hypotheses are based on qualitative evidence. In the present work quantitative data bearing on the hypotheses were obtained by comparing in vitro the rates of urea breakdown, ammonia production, respiration, and acid secretion, of isolated frog gastric mucosae. These experiments, and measurements of the urea content of frog gastric mucosae and mouse stomachs, show that gastric urease plays no direct role in the mechanism of acid secretion. Any neutralization of acid in our experiments is also excluded.

Part of this work has been communicated to the Biochemical Society (Davies \& Kornberg, 1950a).

\section{METHODS}

Estimation of tissue urea. Large frogs (Rana temporaria temporaria L.) were pithed and the gastric mucosae rapidly dissected out and washed, according to the procedure of Davies $(1948 a)$. The wet mucosae were blotted and small pieces snipped off from the corpus regions for estimation of urease activity. The remaining tissue was rapidly weighed on a torsion balance and dropped into $5 \mathrm{ml}$. boiling water to destroy any gastric urease activity. Mice were killed by decapitation and the stomachs cut open, washed and treated as above.

After $4 \mathrm{~min}$. boiling, the mixture was finely ground with a little acid-washed sand. Samples (1-2 ml.) of these mixtures were pipetted into the main compartments of Warburg vessels, together with $0.3 \mathrm{ml}$. 3 M-acetate buffer (pH 5.0) and $0.7 \mathrm{ml}$. water. The urea content was estimated manometrically at $38^{\circ}$ by addition of $0.5 \mathrm{ml}$. jack bean urease solution. This enzyme solution was prepared by shaking $10 \mathrm{~g}$. finely ground, sieved jack bean meal with $100 \mathrm{ml}$. water and $10 \mathrm{ml} .3 \mathrm{M}$-acetate buffer (pH 5.0) for $2 \mathrm{hr}$. After addition of two drops iso-octanol, the supernatant liquid was used as the enzyme source.

Estimation of tissue urease activity. The pieces of frog gastric mucosa, or of whole mouse stomach, obtained as above, were weighed and ground with a little sand and 5 vol. water. Samples $(1 \mathrm{ml}$.) of the resultant suspensions, together with $3 \mathrm{ml} . \mathbf{0} 3 \mathrm{~m}$-acetate buffer (pH 5.0) were pipetted into the main compartments of double side-armed Warburg vessels, and, after equilibration at 25 or $38^{\circ}, 0.4 \mathrm{ml} .0 \cdot 275 \mathrm{M}$ urea solution was added from a side arm. The urease activity of the ground tissue was calculated as $Q_{\text {urea }}$ from the rate of evolution of carbon dioxide. An hour after the addition of the urea, jack bean urease was added from the second side arm. The immediate evolution of $\mathrm{CO}_{2}$ showed that any lack of effect with the ground tissue was due to an absence of urease activity and not to possible faults in technique.

Measurement of acid production by tied bags of frog gastric mucosa. The amounts and rates of acid secretion and respiration of histamine-stimulated isolated tied bags of frog gastric mucosa were measured manometrically at $25^{\circ}$ by the method of Davies (1948a). In some of the experiments, urea (final concentration 2,10 or $20 \mathrm{~mm}$ ) was added to the tissues initially or during the course of the incubations (3-5 hr.).

Estimation of ammonia. The ammonia content of the incubation media, and the secretions formed in the tied bags of mucosa, were determined by the method of Conway (1947). The boric acid + indicator solution in the centre wells of the Conway units was quantitatively transferred to small tubes and titrated against $0.015 \mathrm{~N}-\mathrm{HCl}$ run in from a Gilmont ultramicroburette. By this procedure the formation of less than $0 \cdot 1 \mu \mathrm{mol}$. ammonia could have been detected.

Estimation of urea in media. The urea contents of the media were estimated manometrically with jack bean urease.

Units. All $Q_{\mathrm{X}}$ values are in $\mu \mathrm{l}$. $\mathrm{X} / \mathrm{mg}$. dry wt. of tissue/hr., where $22.4 \mu \mathrm{l}$. $\mathrm{X}$ is equivalent to $1 \mu \mathrm{mol}$. $\mathrm{X}$.

\section{RESULTS}

The urea content of frog gastric mucosa. The urea content of ten (pooled) samples of frog gastric mucosa is shown in Table 1. The average value was $0.039 \mu \mathrm{mol} . / \mathrm{mg}$. dry wt. This is $0.05 \%$ wet wt., or 


\section{Table 1. Urea content of frog gastric mucosa and of mouse stomach}

(Tissue rapidly washed, weighed and dropped into $5 \mathrm{ml}$. boiling water. Boiled for 4 min., ground with sand, and samples estimated manometrically for urea with jack bean urease in $0 \cdot 3 \mathrm{M}$-acetate buffer, $\mathrm{pH} 5 \cdot 0$.)

$\begin{array}{ccccc} & \text { Total } & \begin{array}{c}\text { Total urea } \\ \text { dry wt. } \\ \text { Tissue }\end{array} & \begin{array}{c}\text { Urea } \\ \text { content } \\ (\mu \mathrm{mol})\end{array} & \begin{array}{c}\text { Urea } \\ \text { concentration } \\ \text { ( } \mu \text { mol./mg. dry wt. })\end{array} \\ \text { Frog gastric mucosa } & 3 & 58 & 2 \cdot 4 & 0 \cdot 041 \\ & 3 & 57 & 2 \cdot 3 & 0 \cdot 040 \\ \text { Mouse stomach } & 2 & 58 & 2 \cdot 2 & 0 \cdot 375 \\ & 2 & 61 & 2 \cdot 35 & 0 \cdot 385 \\ & 3 & 125 & 1 \cdot 8 & 0 \cdot 014 \\ & 2 & 90 & 1.5 & 0.0165\end{array}$

8.3 mm. Five samples of whole mouse stomach (Table 1) had an average urea content of $0.015 \mu \mathrm{mol} . /$ mig. dry wt., this being $0.019 \%$ wet wt. or $3.2 \mathrm{~mm}$.

The urease activity of frog gastric mucosa and mouse stomach. Estimations were made of the urease activity of thirty-seven ground frog gastric mucosae. Twenty-nine mucosae showed no trace of urease activity, and the $Q_{\text {ures }}$ was therefore smaller than -0.02. Six of these samples were from mucosae which had been actively secreting acid in vitro with $Q_{\text {BCl }}$ values up to $5 \cdot 1$. It may be that in these twenty-nine mucosae the urease was present but completely inhibited. This possibility cannot be excluded but is unlikely, because added jack bean urease was not inhibited. Urease activity was found in the remaining eight mucosae, with $Q_{\text {urea }}$ values ranging from $-1 \cdot 15$ to $-1 \cdot 50$, average $\mathbf{- 1 . 3 8}$. It is not known whether these mucosae were capable of secreting acid, but this is likely as the experiments were carried out in spring (Bradford, Crane \& Davies, 1950). No urease activity was found in any of eight unground open sheets of frog gastric mucosa. In contrast to these results, urease activity was found in all of ten mouse stomachs. The $Q_{\text {urea }}$ values ranged from $-3 \cdot 6$ to $-6 \cdot 8$, average $\mathbf{- 5 \cdot 2}$.

The effect of urea on ammonia formation by frog gastric mucosa. Since the ammonia produced by gastric urease activity is not preferentially incorporated into the proteins of the gastric mucosa (Davies \& Kornberg, 1950b) a maximum figure for the urease activity can be derived from the ammonia produced during the course of an experiment. Assays were made of the ammonia content of the media in twenty-two experiments. Eighteen of these contained urea ( $10 \mathrm{~mm})$, and in ten of these the mucosae were stimulated to secrete acid. Four of the mucosae were incubated in the absence of urea, and two of these secreted acid. In no case was ammonia detected. in the medium. The secretions from ten mucosae were also assayed for ammonia. Six of the mucosae had been incubated in the presence of urea (10 $\mathrm{mm})$ and five of them had secreted acid. Two of the remaining four mucosae incubated in the absence of urea had also secreted acid. No trace of ammonia was found in any of these secretions.

Control estimations showed that the method used was sensitive to less than $0.1 \mu \mathrm{mol}$. of ammonia. This means that the $Q_{\mathrm{NH}_{3}}$ was less than $0 \cdot 01$.

The recovery of added urea. In order to test the possibility that the urea was being metabolized by mechanisms not leading to the formation of ammonia, estimations were made of the urea content of twelve of the media after incubation. In all cases quantitative recovery of the urea was obtained within the experimental error, which was estimated as $\pm 2 \%$

The effect of urea on the respiration and acid secretion of frog gastric mucosae. In more than a thousand experiments previously carried out in this laboratory, it had been found that isolated frog gastric mucosae can respire, and secrete acid, in the entire absence of external supplies of urea. In four experiments urea was added to final concentrations of 1.7 or $17 \mathrm{~mm}(0.01$ or $0.1 \%) 1 \mathrm{hr}$. after the beginning of incubation. These additions caused no changes in the rates of respiration during the course of the experiments ( $4 \mathrm{hr}$.).

The rates of acid secretion produced by isolated frog gastric mucosae showed large individual variations (Davies, 1948a; Bradford et al. 1950) both in the maximum rates and in the quantities of secretions produced. In thirty-eight experiments urea was added, to final concentrations of 2,10 or $20 \mathrm{~mm}$, either initially or during the counse of incubations lasting 3 or $5 \mathrm{hr}$. These additions had no effect on the rates of acid secretion when secretion had already commenced. Normal secretory responses occurred in all cases in which histamine was added either simultaneously with, or after, addition of urea. $Q_{\mathrm{HCl}}$ values greater than 3 were regularly obtained. Some mucosae had $Q_{\text {HCl }}$ values greater than 5, and more than $18 \mu \mathrm{mol}$. hydrochloric acid were secreted during the course of the experiment. The urea content of the mucosa was, however, only $0.5 \mu \mathrm{mol}$. 


\section{DISCUSSION}

The role of gastric urease in acid secretion. The hydrogen ions formed by the stomach were thought by Mathews (1925) to be derived from ammonium ions, the ammonia being either absorbed or turned into 'ureido or carbamido compounds'. This view was accepted by Rigoni (1930), Martin (1932), Cardin (1933), Mann \& Mann (1939), and Martinson (1950), who thought that gastric urease provided the ammonium ions from the hydrolysis of urea. Glick $(1949 a)$ considered the possibility that the ammonium ions were exchanged with hydrogen ions of the blood during acid secretion.

There are several lines of evidence against these views. Isolated gastric mucosa can secrete acid in the absence of added urea or ammonia, as has been shown for frogs and toads (Delrue, 1930; Gray, Adkison \& Zelle, 1940; Teorell \& Wersäll, 1945; Davies, 1946; Edwards \& Edwards, 1948) and for the stomach or gastric mucosae of mice, rats, cats, dogs and polecats (Davies, 1946; Davenport \& Jensen, 1948; Coy \& Rehm, 1948; Patterson \& Stetten, 1949; Bradford \& Davies, 1950). The addition of urea does not lead to an increase in the amounts of acid secreted by isolated mouse stomachs (Davenport \& Jensen, 1949) or frog gastric mucosae (Davies \& Kornberg, 1950a ; Glick, Zak \& von Korff, 1950), and causes no detectable increase in respiration. In some species urea in sufficiently large amounts may cause inhibition of acid secretion (FitzGerald \& Murphy, 1950; Glick et al. 1950).

The results described in this paper show that isolated frog gastric mucosae can secrete more than thirty times the amount of hydrochloric acid that could possibly be made from the tissue store of urea, even if the whole of this were available to the oxyntic cells. Isolated mouse stomach (Davies, $1948 b$; Davenport \& Jensen, 1948, 1949) can secrete more than $1 \mu \mathrm{mol}$. hydrochloric acid/mg. dry weight in the absence of added urea. This is more than fifty times the amount of urea in the tissue.

Therefore the urea store of the gastric mucosa in both frogs and mice cannot account for the quantities of hydrochloric acid which are secreted in vitro.

The remaining possibility is that oxyntic cells possess a mechanism which can synthesize urea at one point and hydrolyse it at another. Such a system could lead to the formation of hydrochloric acid, the ultimate source of the hydrogen ions in this case being water (Davies, 1948 $a, 1951$ ). There is no evidence for the occurrence of an urea-synthesizing mechanism in gastric mucosa (Krebs, 1934; FitzGerald \& Murphy, 1948), and it has been shown that the location of the urease in the gastric mucosa is in cells other than oxyntic cells (LinderstrømLang \& Ohlsen, 1936; Ohlsen, 1941; Fossel, 1947). FitzGerald \& Murphy (1949), and FitzGerald (1951), using the technique of Sen (1930), claim to have located the urease in the cells surrounding the oxyntic cells, although FitzGerald \& Murphy (1950), using the same technique, suggest that the enzyme is actually present in the oxyntic cells. The staining technique used has been found to be unreliable (Glick, 1949b; Davies \& Kornberg, unpublished experiments), as it can be made to demonstrate an apparent localization of urease in tissues definitely known not to have urease activity.

Further evidence against this possibility is the fact that in isolated gastric mucosa the rate of urea breakdown is usually many times less than the rate of acid secretion (Davenport \& Jensen, 1949; Davies \& Kornberg, 1950 a ; Glick et al. 1950). It has also been shown in the present paper that high rates of acid secretion can be observed in mucosae free from urease activity.

The evidence thus appears conclusive that gastric urease plays no direct role in the mechanism of acid secretion, a view now accepted by Glick and his coworkers (Glick et al. 1950).

The protective role of urease in gastric mucosa. It has frequently been suggested that gastric urease plays a role in protecting the mucosa from attack by acid and pepsin (Luck \& Seth, 1925 ; LinderstrømLang \& Ohlsen, 1936; Ohlsen, 1941; FitzGerald, 1946; Fossel, 1947; FitzGerald \& Murphy, 1950; Glick et al. 1950). The present results show that any neutralization of acid by ammonia was quantitatively insignificant with Rana temporaria. Ammonia was not detectable in either the secretions or the media after incubation of gastric mucosa in the presence or absence of urea for 3 or $5 \mathrm{hr}$. These results differ from those of Glick et al. (1950), who used Rana pipiens as experimental material and reported the presence of ammonia in secretions and media, in the average ratio of $4: 1$ in absence of added urea, and 2.7:1 in presence of $0 \cdot 1 \%$ urea. The ammonia concentrations reported by Glick and his co-workers are more than three hundred times greater than would have been detected in our experiments. This difference in results may be due to differences in the biological material used.

\section{SUMMARY}

1. The average urea content of frog gastric mucosa was found to be $0.039 \mu \mathrm{mol} . / \mathrm{mg}$. dry wt. (8.3 mM, wet wt.). In whole mouse stomach the average concentration was $0.015 \mu \mathrm{mol} . / \mathrm{mg}$. dry wt. (3.2 mM, wet wt.).

2. Urea (2, 10 or $20 \mathrm{~mm})$ did not affect the rates of respiration or acid secretion of isolated frog gastric mucosae.

3. The urease activity of ground samples of frog gastric mucosa was low and very variable; only eight out of thirty-seven samples contained any 
activity. Active urease preparations were obtained from all mouse stomachs examined.

4. None of thirty intect frog gastric mucosae showed any urease activity. The incubation media or secretions of resting or acid-secreting tied bags of mucosa contained no detectable quantities of ammonia, either in presence or absence of urea. Added urea was recovered quantitatively. Any acid-neutralizing role of urease in these experiments is thus excluded.

5. The amounts of acid secreted by isolated frog gastric mucosa or whole mouse stomach in absence of added urea were more than thirty times the urea content of the tissue.

6. Since there is no evidence that urea is synthesized by gastric mucosa, it follows that urea and urease play no direct or catalytic role in the mechanism of acid secretion.

We wish to thank Prof. H. A. Krebs, F.R.S., for his encouragement and interest in this work. One of us (H.L.K.) wishes to acknowledge the receipt of a grant from the Medical Research Council.

\title{
REFERENCES
}

Bradford, N. M., Crane, E. E. \& Davies, R. E. (1950). Proc. zool. Soc. Lond. 120, 471.

Bradford, N. M. \& Davies, R. E. (1950). Biochem. J. 46, 414. Cardin, A. (1933). Arch. Sci. biol., Napoli, 19, 76. (Seen in Ber. ges. Physiol. 1934, 77, 102.)

Conway, E. J. (1947). Microdiffusion Analysis and Volumetric Error, p. 85. London: Crosby, Lockwood and Son Ltd.

Coy, F. E. \& Rehm, W. S. (1948). Amer. J. Physiol. 155, 431.

Davenport, H. W. \& Jensen, V. (1948). Gastroenterology, 11, 227.

Davenport, H. W. \& Jensen, V. (1949). Gastroenterology, 12, 630.

Davies, R. E. (1946). Biochem. J. 40, xxxv.

Davies, R. E. $(1948 a)$. Biochem. J. 42, 609.

Davies, R. E. (1948b). The Mechanism of Hydrochloric Acid Production by the Stomach. Ph.D. Thesis, University of Sheffield.

Davies, R. E. (1951). Biol. Rev. 26, 87.

Davies, R. E. \& Kormberg, H. L. (1950a). Biochem. J. 47, ii.

Davies, R. E. \& Kornberg, H. L. (1950b). Biochem. J. 47, viii.

Delrue, G. (1930). Arch. int. Physiol. 33, 196.

Edwards, L. E. \& Edwards, C. T. (1948). Fed. Proc. 7, 30.

FitzGerald, O. (1946). Nature, Lond., 158, 305.

FitzGerald, O. (1951). Gastroenterologia, 76, 86.
FitzGerald, O. \& Murphy, P. (1948). Nature, Lond., 162, 896.

FitzGerald, O. \& Murphy, P. (1949). Lancet, 2, 1107.

FitzGerald, O. \& Murphy, P. (1950). Irish J. med. Sci. p. 97. Fossel, M. (1947). Hoppe-Seyl. Z. 282, 164.

Glick, D. (1949a). J. Nat. Cancer Inst. 10, 321.

Glick, D. (1949b). Advanc. Enzymol. 8, 589.

Glick, D., Zak, E. \& von Korff, R. (1950). Amer. J. Physiol. $163,386$.

Gray, S. J., Adkison, J. L. \& Zelle, K. (1940). Amer. J. Physiol. 130, 327.

Krebs, H. A. (1934). Ergebn. Enzymforsch. 3, 247.

Linderstrøm-Lang, K. \& Ohlsen, A. S. (1936). Enzymologia, $1,92$.

Luck, J. M. (1924). Biochem. J. 18, 825.

Luck, J. M. \& Seth, T. N. (1925). Biochem. J. 19, 357.

Mann, F. D. \& Mann, F. C. (1939). Amer. J. digest Dis. 6, 322.

Martin, L. (1932). Trans. Amer. Gastroent. Ass. 35, 3.

Martinson, E. E. (1950). Biochimia, 15, 121.

Mathews, A. P. (1925). Physiological Chemistry, 4th ed. London: Baillière, Tindall and Cox.

Ohlsen, A. S. (1941). C.R. Lab. Carlsberg, 23, 329.

Patterson,W.B. \& Stetten, D., jun. (1949). Science, 109, 256.

Rigoni, M. (1930). Arch. ital. Biol. 24, 74.

Sen, P. B. (1930). Indian J. med. Res. 18, 79.

Teorell,T.\& Wersäll, R.(1945). Acta physiol.Scand.10, 243.

\section{The Specificity of Cobra-venom Cholinesterase}

\author{
BY L. A. MOUNTER \\ Department of Biochemistry, University of Oxford
}

(Received 4 May 1951)

The high concentration of cholinesterase in cobra venom was first noted by Jynegar, Sehra, Mukerji \& Chopra (1938). The enzyme is present in the venom of the Colubridae, though absent from that of other genera, notably the Viperidae (Jynegar et al. 1938; Ghosh, Dutt \& Chowdhury, 1939; Ghosh, 1940; Zeller, 1949). Following the recognition of two types of cholinesterase, Zeller \& Maritz (1945) and Zeller (1947) classified cobra-venom cholinesterase as an e-type or 'true' cholinesterase.
Bovet-Nitti $(1947 a, b)$ studied the esterase specificity of cobra venom. She reported that a number of aliphatic esters such as the glycol and glycerol acetins and ethyl acetate were hydrolysed, but that tributyrin, ethyl propionate, amyl acetate and the choline esters of the higher fatty acids were not hydrolysed. The rate of hydrolysis of the $n$ alkyl acetates fell rapidly with increasing chain length. She assumed that the same enzyme was responsible for the hydrolysis of both acetylcholine 